\title{
Grundtvig, dyden og kærligheden
}

\section{Af Ole Nyborg}

Dyden har i løbet af de sidste 150 år fået et dårligt rygte. Den amerikanske moralfilosof MacIntyre har beskrevet dydsbegrebets historie siden Homer og Aristoteles, og han gennemgår også, hvordan selve begrebet ændrer indhold i den almindelige europæiske sprogbrug i løbet af det 19. århundrede (MacIntyre 1981). Fra at blive anvendt om den almindelige godhed eller moralske kraft og evne hos mennesket bliver begrebet "dyden" i stigende grad i løbet af det 19. århundrede anvendt om unge pigers og kvinders seksuelle selvkontrol og dyder på seksuallivets område. Men begrebet dyden har en lang historie i den europæiske filosofi og teologi.

Grundtvig-forskningen har ikke beskæftiget sig meget med Grundtvigs forhold til dydsbegrebet, men i det følgende vil repræsentative eksempler fra Grundtvig-forskningen blive omtalt. Derefter vil Grundtvigs brug af dydsbegrebet blive undersøgt ved en række eksempler specielt $i$ forbindelse med hans tale om kærligheden. Tekstmaterialet til denne undersøgelse er Grundtvigs prædikener i Vartov i 1840 'erne. En placering af Grundtvigs forhold til dydsbegrebet er interessant især på grund af den omfattende interesse, som begrebet "dyden" har fået siden 1990'erne i den nyaristoteliske filosofi og etik og $\mathrm{i}$ form af den såkaldte dydsetik (fx Swanton 2003, McDowell 1998, Christensen 2008, Darwall 2003).

\section{Grundtvigforskningen om Grundtvig og dyden}

Kaj Thaning har i sin disputats om Grundtvig (Thaning 1963) indgående beskæftiget sig med Grundtvigs tanker om kærligheden, men Thaning mener ikke, at Grundtvigs tanker om kristendommen eller kærligheden har nogen sammenhæng med en tanke om dyden. Grundtvig kan derimod godt tale om dyden i en samfundsmæssig eller borgerlig sammenhæng, og Thaning giver en skildring heraf (Thaning 1963, 374). Grundtvig er i sin kristendomsopfattelse generelt modstander af rationalisternes tale om dyden (643). Oprindeligt har Grundtvig dog en "moralistisk" opfattelse af menigheden og kristendommen, men i 1832 omvender Grundtvig sig til virkeligheden og opgiver denne moraliserende tendens (643). Før 1832 kan Grundtvig godt tale om menigheden som et helligt og rent samfund, men derefter taler han om det almindelige borgerlige menneskeliv (643). Kærligheden hos Grundtvig er ikke en dyd og har intet med dyden at gøre (646 f.). På trods heraf bringer Thaning flere citater, hvor Grundtvig direkte udtrykker sin enighed med rationalisternes tale om dyden (646 f.): Thaning citerer således en udtalelse af Grundtvig fra 1842 om det 18. århundredes dydsprædikanter: "baade Udtrykkene, de tog af Skriften (...) [var] uforbederlige, og Moraliseringen (...) langt nyttigere end 
Dogmatiseringen efter de Symbolske Bøger og Pietismen i de gudelige Forsamlinger, thi disse førde fra, men hin sigtede dog til Livet i Christus" (citeret Thaning 1963, 647, Grundtvigs markering).

Erik Krebs Jensen har givet en udførlig gennemgang af Grundtvigs tanke om hjertets gudbilledlighed (Jensen 1977). Da begrebet dyden hos Grundtvig synes at have en sammenhæng med hans begreb om "Hjertet", er Krebs Jensens gennemgang i høj grad relevant for den efterfølgende undersøgelse. Ifølge Krebs Jensen er "Hjertet" hos Grundtvig et modtagende og gengivende element, idet "Hjertet" modtager Guds ord og kaster det tilbage til Gud som en genlydsmur eller et spejl (94 f.). Hjertet er "menneskets modtagende egenskab" (95). Hjertet er en mur, som - hvis den vender rigtigt - tilbagekaster Guds ord (69). Hjertet hos Grundtvig synes derfor at være noget grundlæggende passivt, som ikke i sig selv optræder som en handlende komponent i mennesket. Grundtvig vendte sig imod rationalisterne og deres tale om fornuften, og når Grundtvig taler om "Hjertet", mener han menneskets følelser (70). Hjertet hos Grundtvig hænger især sammen med attrå og længsel (75). Ifølge Krebs Jensen er følelserne nu blevet undertrykt i kirken og i det moderne samfund, og derfor bør vi lade os inspirere af Grundtvig og tale mere om vores følelser (71). "Grundtvig så følelsens betydning (...) for menneskets tankegang og handlinger, ja han regnede følelsen for den vigtigste grund" (71). "Arbejdet med Grundtvigs hjertebegreb har gjort det indlysende, at der igen må tales teologisk om følelser" (71). Krebs Jensen synes derudover at beskrive "Hjertet" hos Grundtvig på en overvejende statisk måde. I Krebs Jensens gennemgang er det svært at se, at det kristne menneske ifølge Grundtvig skulle gennemløbe nogen vækst eller udvikling (jf. 95 f.). Krebs Jensen opfatter ikke Grundtvigs tale om "Hjertet" som udtryk for noget skema om dyden på trods af de Grundtvig-citater, som han bringer, hvor Grundtvig udtrykkeligt taler om "Dyden" (75).

Lise Brandt Fibiger har givet en indgående gennemgang af Grundtvigs væksttanke især i hans salmer (Fibiger 1977). Fibiger opfatter heller ikke Grundtvigs tanker som på nogen måde relateret til et dydsskema. Det kan overraske i betragtning af de Grundtvig-citater, som bringes i Fibigers artikel $(227,229)$, hvor Grundtvig på en meget markant måde taler om de kristelige dyder. Fibiger bruger ikke begrebet dyd i sin artikel, og det er tydeligt, at tro, håb og kærlighed hos Grundtvig ikke skal opfattes som kristelige dyder (227). Grundtvigs tanke er, at vi bliver ved med at være som børn hele livet (226 f.). Tro, håb og kærlighed er både sideordnede og successive stadier hos Grundtvig, men Fibiger lægger tilsyneladende mest vægt på, at de tre momenter er sideordnede og til stede hos barnet fra 
begyndelsen (228). Hos Grundtvig finder vi tilsyneladende ikke en egentlig vækst fra barn til den fuldvoksne mand, hvor der sker en virkelig forandring af menneskets karakter eller væsen, og det kristne menneske bliver ved med at vende tilbage til startpunktet for dets udvikling $(231,246)$. Grundtvig tolkes - som hos Thaning - som en slags skabelsesteolog, og Fibiger lægger vægt på, at Grundtvig taler om kontinuiteten mellem det menneskelige og det kristelige (228, $245 \mathrm{f}$.). Grundtvig var ikke - og her polemiserer Fibiger mod P. G. Lindhardt tilhænger af nogen "udviklingstanke" (246). Grundtvigs tanke er ikke, at vi skal hæve os op over verden eller det jordiske (246). Ligesom Thaning og Krebs Jensen fortolker Fibiger Grundtvigs teologi inklusive hans eventuelle forhold til dydsbegrebet - på en sådan måde, at den $\mathrm{i}$ en vis forstand er forenelig med den dialektiske teologi i det 20. århundrede.

Henning Høirup (1983) kommenterer et par steder Grundtvigs forhold til dyden. Høirups bog er et slags forsvar for Grundtvig over for en kritik, som Hal Koch i 1950-51 rettede imod Grundtvig for at ignorere basale menneskelige kendsgerninger som døden og næsten (27 f.). Høirup kommenterer et sted Grundtvigs forhold til den autoriserede Evangelisk-kristelig Salmebog og siger i den forbindelse, at hos Grundtvig finder vi ikke denne salmebogs tanker om "fremgang i karakterudvikling" eller - med et citat fra den - tanker om "ædel Væxt i Dyd og Troe" (54). Hos Grundtvig møder vi ikke nogen tanke om, at døden skal lære os at "vorde gode Mennesker" (54, med et citat fra salmebogen). Høirup tilføjer, at vi nemt kan forestille os, hvilken "lidelse" denne "dydige moralisering" var for Grundtvig (54). Længere fremme i bogen henviser Høirup til en tanke hos $\mathrm{H}$. N. Clausen om, at der er en forbindelse mellem "Dyden" og "Udødeligheden", og Høirup skriver, at hele denne tanke klart blev afvist af Grundtvig (63). Også i sin disputats om Grundtvigs erkendelsesteori og forhold til modsigelsens grundsætning (Høirup 1949) anfører Høirup adskillige citater af Grundtvig, hvor begrebet "Dyden" optræder, men Høirups mening synes at være, at Grundtvig ikke er bestemt af noget dydsskema (fx Høirup 1949, 101, 163, 166).

Den norske teolog Synnøve Heggem (2005) har givet en omfattende skildring af Grundtvigs kærlighedstanke især i hans salmer (jf. også Heggem 2000 og 2007). Heggem afviser, at Grundtvig skulle opfatte kærligheden som en dyd. Hvis man skildrer kærligheden som en dyd, bliver kærligheden "koloniserende" og "imperialistisk", fordi det er dydens væsen at være koloniserende og imperialistisk (He'ggem $2005,187)$. Heggem synes at definere dydsbegrebet ved en tanke om "plikt" (187), men forklarer ikke yderligere, hvad hun forstår ved dydsbegrebet. Heggem synes ikke at tale om dydsbegrebet i dets 
klassiske betydning, som vi finder det hos Aristoteles, Platon eller Thomas, men ud fra hendes samlede skildring af Grundtvigs kærlighedstanke er det tydeligt, at hun mest opfatter kærligheden hos Grundtvig som en følelse.

Regner Birkelund (2008) beskriver dydsbegrebet hos Aristoteles og sætter det $\mathrm{i}$ forbindelse med Grundtvigs opfattelser af menneske og frihed og tanker om det fælles bedste, men Birkelund forbinder ikke dydsbegrebet med Grundtvigs kristendomsforståelse. Grundtvigs tanker vedrørende samfundets indretning svarer ifølge Birkelund til tankerne hos Platon og Aristoteles (Birkelund 2008, 242). Birkelund beskriver dyden hos Aristoteles som den dyd at få gode venner og den dyd at lægge vægt på venskabet (242). Ifølge Birkelund mener både Aristoteles og Grundtvig, at alle mennesker fra naturens hold er født med et "etisk potentiale", og at mennesker derfor grundlæggende er lige ( $242 \mathrm{f}$.). Birkelund synes her at overse den markante opfattelse af menneskers ulighed og opfattelsen af, at der er gode og slette mennesker, som man finder hos Aristoteles, og som netop er et fundamentalt træk i hans dydsteori (242 f., 244). Den omfattende diskussion af dydsbegrebet, som er foregået i den ny-aristoteliske dydsetik siden 1990'erne, inddrages ikke direkte hos Birkelund.

Herudover er en række andre værker, som indgående beskæftiger sig med Grundtvigs kærlighedstanke, blevet undersøgt for at afgøre, om disse værker sætter Grundtvigs kristendomsopfattelse eller kærlighedsopfattelse i forbindelse med et begreb om dyden. Det gælder blandt andet: Allchin (1997), Balslev-Clausen (1991), Borum (1983), Bjerg (2002), Brandt-Nielsen (1993), Elbek (1960), Gregersen (2000), Grønbæk (1951), Hansen (1997), Iversen (1987) og Jonas (2007). Ingen af disse fremstillinger af Grundtvigs kristendoms- eller kærlighedsopfattelse sætter hans tanker i forbindelse med et dydsbegreb eller overhovedet med en tale om dyden (jf. også oversigten over Grundtvig-litteraturen i Jørgensen 2009).

\section{Eksempler på Grundtvigs brug af selve begrebet "Dyden"}

Der er fire helt forskellige problemstillinger i forbindelse med spørgsmålet om et dydsbegreb hos Grundtvig: Det første spørgsmål er, om man kan sige, at Grundtvig - i de tilfælde, hvor han eksplicit anvender begrebet "Dyd" - går ud fra et underliggende dydsskema som sådan. Det andet problem vedrører selve indholdsbestemmelsen af dyden eller dyderne. Er for eksempel kærligheden en dyd? Det tredje spørgsmål er, om man helt generelt kan finde et dydsskema i Grundtvigs kristendomsforståelse - helt uanset, om han eksplicit anvender begrebet "dyd". Og endelig: Hvordan forholder han sig på den måde til 
den lange teologiske og filosofiske tradition, som har talt om dyden eller dyderne? I det følgende vil kun de to første spørgsmål blive søgt besvaret.

Grundtvig anvender begreber som "Dyd" og "dydig" i et overvældende stort antal tilfælde i sine Vartov-prædikener. ${ }^{1}$ I det følgende skal gennemgås udvalgte eksempler på hans brug af dydsbegrebet og hans overvejelser omkring begrebet "Dyden".

\section{Dyden og det realt mulige}

I en prædiken på den 2. søndag i advent 1844, hvor Grundtvig taler om verdens undergang, kommer han ind på begrebet om dyden (GPV VII, 10-16; teksten er Luk 21,25-36). Vi er ifølge Grundtvig endnu langt fra at være fuldkomne. Vi er hverken "fuldkommen giennemtrængt af Herrens Aand" eller "fuldkommen oplyst" (GPV VII, 12). Grundtvig omtaler en lang række dyder, som han kalder de "Apostoliske Dyder" såsom "Aand", "Kraft", "Liv", "Lys" og "frem for Alt" "Kiærlighed til Gud og Næsten" (GPV VII, 12). Disse dyder vokser ifølge Grundtvigs prædiken gradvist frem i tiden og i historien. Grundtvigs pointe er, at "vi" endnu ikke - i 1844 - har en tilstrækkelig forståelse af, hvad verdens undergang egentlig er, og at "vi" endnu ikke har den nødvendige kraft og styrke til at stå frem og forkynde og til især at gennemleve verdens undergang. Denne dyd, kraft og styrke vil vi først - eller forhåbentligt - opnå på et senere tidspunkt (GPV VII, 12 f.).

Grundtvigs brug af begrebet "Dyder" indebærer klart nok, at dyden er noget, som vokser eller i al fald kan vokse med tiden, og at dyden er en omfattende evne, der både inkluderer en vis bevidsthed og en vis

1 Eksempler på Grundtvigs brug af begreberne "Dyd" eller "dydig" i hans prædikener 1839-49 er følgende: $G P V$ I, 27 f., 41 f., 58 f., 89, 307, 450 f., 284, 307, 346, 451, 492, 513; GPV II, 73, 77, 216, 278 f., 153, 293, 305; GPV III, 127, 189 f., 301, 352, 256, 358, 386, 405; GPV V, 165, 279, 352; GPV VI, 12 f., 279, 281, 301, 377 f., 380, 387, 395; GPV VII, 138, 165 f., 283 f. samt uden for de trykte prædikener: "Jule-Søndag 1845", "Midfaste Søndag 1846", "Paaske-Søndag 1846", "2den Onsdag i Faste 1847", "Alle-Helgens Dag 1849", "19de Søndag efter Trefoldighed 1849", "2den Helligtrekonger-Søndag 1849", "11te Søndag efter Trefoldighed 1849". De utrykte prædikener foreligger nu også digitalt på internetadressen grundtvig.dk. - I alt er der fundet hen ved 155 passager i disse prædikener, hvor Grundtvig anvender begrebet "Dyd", og et mindre antal steder, hvor han anvender begrebet "dydig". Grundtvig synes i disse prædikener som hovedregel at anvende ordet "dydig" $i$ en negativ betydning som et udtryk for en misforståelse af dydens sande natur (fx $G P V$ I, 58 f., 89, 284; GPV II, 216). - I ganske fă tilfælde anvender Grundtvig begrebet "Dyden" om en tings eller ikke-menneskelig størrelses godhed, egnethed eller kvalitet (fx GPV III, 405). 
moralsk eller menneskelig styrke, evne og kraft. Dydens gerning er ifølge Grundtvigs prædiken at gøre det realt mulige, altså det, som er muligt i forhold til menneskets nuværende forhold og ressourcer. De to størrelser - det, som vi kan, og det, som vi skal - hænger ofte sammen i Grundtvigs prædikener (fx også GPV I, 27), og kærligheden og godheden hænger sammen med det, som vi kan bære og evne, altså med vores "Dygtighed" og "Evne" (fx GPV II, 324, 415; GPV III, 424; $G P V$ V, 270 f.; GPV VI, 121; GPV VII, 256). Vi skal ikke kaste os ud i moralske opgaver eller kristelige gerninger, som vi endnu ikke har styrken og kraften til at gennemføre: "kun en Daare begynder at bygge paa et Taarn uden Midler til at fuldføre det" (GPV VII, 12). En sådan moral eller kristendom ville være den rene "Daarskab". Kærligheden og dyden handler om, hvad vi kan magte, og den handler om vores magt, evne eller mægtighed (jf. også fx GPV III, 424; GPV II, 324; $G P V$ VII, 256; $G P V$ VI, 121; GPV II, 415). Dyden er at gøre, hvad man kan, og at gøre, hvad der er muligt. Grundtvigs mening er, at den apostoliske eller kristelige dyd, hvis kerne er "den inderlige, brændende Kiærlighed" (GPV VII, 13), gradvist vokser frem eller bliver bygget op. Efterhånden som den styrkes og realiseres $\mathrm{i}$ menigheden og i det enkelte kristne menneske, bliver flere og flere moralske og kristelige opgaver realt mulige eller realisable. Målet for dydens udvikling er, at vi som fuldvoksne krigere skal blive tilstrækkeligt kraftige, mægtige og modige til at gå i krig med verden, men vi skal ikke "spilde og udtømme" vore nuværende kræfter "i frugtesløs Kamp og Strid med dem, som er udenfor" (GPV VII, 13 f.). Kærligheden er et spørgsmål om evne, ressourcer, modenhed, mandighed, duelighed og dygtighed (jf. GPV VII, 13). Når Grundtvig taler om kærligheden som kernen i de kristelige dyder, går han altså tydeligt nok ud fra et dydsskema. ${ }^{2}$

I en senere prædiken i Vartov fra 1855 udtrykker Grundtvig en tilsvarende tankegang om sammenhængen mellem dyden, evnen og væksten (Lindhardt 1974, 167). Grundtvig taler om Jesus og hans menneskelige og åndelige udvikling. Først til sidst - hen imod enden på sit jordiske liv - går Jesus for alvor i krig med saddukæerne og farisæerne. Således er det også med os. Vi skal ikke - førend vi har udviklet den fornødne styrke, evne og kraft - kaste os ud i udøvelsen af den fuldstændige kristelige dyd og godhed (Lindhardt 1974, 167 f.).

Thodberg (2007, 333-335) gennemgår Grundtvigs udtalelser om "Dyden", i denne og flere af de behandlede prædikener, men han giver ingen kommentarer til Grundtvigs brug af dydsbegrebet. 


\section{Dyden og det maskuline og fuldvoksne}

I en prædiken fra 1842 kommer Grundtvig ligeledes ind på spørgsmålet om dyden (GPV III, 189-191: "3die Søndag efter Paaske 1842 Aftensang", teksten er 1 Pet 2, 11-20). Meningen med det kristelige liv er, at der skal ske en vækst (jf. Grundtvigs tale om den "guddommelige Væxt" fx GPV II, 60; GPV III, 144, 272; GPV V, 314; $G P V$ VI, 60, 104, 305, "Onsdag 3die Decber 1845", "Skiærthorsdag 1849”). Vi begynder dette liv som børn. Barnet er ikke kommet langt på vækstens eller dydens vej, men efterhånden når vi til sidst frem til fuldkommenheden som fuldvoksne præster og konger. Det, som vokser i løbet af denne vækst, er vores "Lyst" og "Kraft", og det, som sker i forløbet, er, at "vi", som er lemmer på Jesu Kristi legeme, i stigende grad realiserer og manifesterer "Hans Dyder" (GPV III, 189). Væksten af dyden sker inden for rammerne af den lille flok, som vandrer igennem "denne Verden som Fremmede og Udlændinger, der længes efter Fædernelandet (...) Himlen" (GPV III, 189).

Dyden er i Grundtvigs prædiken en dygtighed eller duelighed, som udvikles hen ad vejen. Dens formål er, at "vi" lærer at klare den modstand, foragt, lidelse, uret og forfølgelse, som den lille flok oplever på vejen, ligesom dydens formål er at bringe dem frem til himlen (GPV III, 189 f.). Livet i den lille menighed er derfor et "Helte og Martyr-Liv" (GPV III, 190). Et formål med den dyd, som de kristne skal lære, er, at de med denne kraft og evne skal overvinde og beskæmme verden (GPV III, 190). Dette dydige helte- og martyrliv er ikke et liv for de små og svage, men kun en opgave, som "de Voxne i Herren" kan bære. Målet med udviklingen af dyden er at udvikle det fuldvoksne kristelige menneske, som har kraften, evnen og magten til at følge Kristus. Den udviklede kristelige dyd er i Grandtvigs prædiken en - i al fald efter traditionelle begreber - "maskulin" dyd, som er bestemt af mægtighed, kampevne og selvkontrol og en vis aggressivitet og frygtløshed. Som Grundtvig siger i flere af sine Vartovprædikener: Vi skal iføre os Guds fulde rustning og gå i krig med verden, men det er ikke en opgave, som børn eller kvinder kan løfte (fx $G P V$ I, 527).

Dette meget "maskuline" dydsskema findes mange steder i Grundtvigs prædikener (GPV II, 328; GPV VI, 244; GPV I, 273; GPV VI, 134; $G P V$ VI, 137; GPV VI, 138; GPV III, 109; GPV III, 112; $G P V$ I, 164; $G P V$ I, 527). ${ }^{3}$ Krigen med verden raser ifølge Grundtvig

3 Lige modsat fortolker fx Heggem (2005) og Birkelund (2008) Grundtvigs kristendom som præget af et "feminint" skema. Jf. også Magnus Stevns' analyser af Grundtvigs salmer (Stevns 1950). - I Grundtvigs Vartov-prædikener 1839-1849 synes kvinder og børn at være præget af en grad af svaghed, 
allerede nu ( $G P V$ VI, 137), og Kristus er i krig med verden ( $G P V$ I, 273). Det er ifølge Grundtvigs prædikener farligt at glemme, at "vi" er i krig med verden, og det er netop en stor fristelse for de sande kristne at glemme dette ( $G P V$ VI, 134). Kristus er en stor "Krigsmand" (GPV III, 112). Sammenhængen mellem det at bekende troen for verden og krigen mellem verden og lysets børn spiller i det hele taget en meget fremtrædende rolle i Grundtvigs prædikener 1839-49, og de dyder, som denne krig og kamp kræver, er tydeligt nok skildret $\mathrm{i}$ meget "maskuline" vendinger. Det er "vores" opgave og ikke kun Kristi opgave at gå i krig med "Verden". Jesu Kristi menighed er i Grundtvigs prædikener et lille tappert skib, som sejler på det store farefulde hav, og som hele tiden angribes og beskydes af overmodige og aggressive sørøverskibe med kugler og kanoner (GPV I, 232). Den kristelige dyd viser sig ved, at de kristne mænd kæmper for Guds rige og for Guds sag. De fuldvoksne kristelige mænd er "Kongens staaende Krigshær" (GPV III, 109) og "vældige Kæmper, som øve sande Heltegierninger" ( $G P V$ I, 129, jf. derudover fx $G P V$ I, 129, 232, 273; GPV VI, 134 f., 138 f.; GPV III, 109, 112). De dyder, som skal erhverves af "Herrens Stridsmænd", er især "Visdom", "Kraft", "Klarhed", "den høie Rolighed" i krigens tummel og virvar og "den himmelske Munterhed" under kampen og krigen (GPV III, $38 \mathrm{f}$.).

Men udviklingen af denne kristelige dyd er ifølge Grundtvig ikke som han hævder, at mange teologer mener - "en ny Lov, der endnu er meget strængere end den Gamle" (GPV III, 190). Grundtvig angriber de "Skriftkloge" for deres fortolkning af dette kristelige liv:

Alt dette finde nu vel de Skriftkloge er en herlig Sag, og at det just giør vor Læremester Jesus Christus udødelig Ære, at Hans Lov og Sædelære er endnu meget strængere, dydigere, renere og aandeligere end den Mosaiske, men det finde og udraabe de dog kun, fordi de tage sig Sagen let og binde svare Byrder til andre, som de ikke selv røre med en Finger (GPV III, 190).

Dyden kan ikke fremkomme ved en etisk regel eller ved et etisk ideal formuleret på en abstrakt måde. Det er den fejl, som de skriftkloge begår. De løfter det etiske ideal helt op til skyerne og fryder sig ved Herrens høje krav til menneskene - men de har ingen som helst anvisning på, hvordan et sådant højt ideal kan realiseres. Grundtvig afviser ikke en tale om kristendommen som en etik, men han afviser den form for kristelig etik, som han øjensynligt finder udbredt $i$

afhængighed eller uudviklethed. Eksempler herpå er: GPV VI, 270;GPV VII, 277; $G P V$ V, 14; GPV I, 165; GPV I, 527; GPV II, 396; GPV VI, 368. I Grundtvigs prædiken "4de Trinitatis-Søndag 1848" er kvinder og børn forbundet med noget blødagtigt. Samme tanke findes i GPV II, 148. 
samtiden. Grundtvigs henvisning til dem, som binder "svare Byrder" paa andre, findes mange forskellige steder i hans prædikener, og meningen med dette udtryk er antageligt en kritik af den kantianske etik (fx $G P V$ II, 293; $G P V$ II, 262; $G P V$ III, 190; $G P V$ V, 166; $G P V$ II, 203; GPV VI, 368; GPV I, 487).

Grundtvig siger i den nævnte prædiken fra 1842, at det er ikke nok at sige, hvad der skal gøres. Kristendommen handler ikke om kun at udtale, at vi skal vende verden og synden ryggen eller gøre det gode. Kristendommen handler om, at vi rent faktisk skal gøre det, og om, hvordan vi kommer til at gøre det. Meningen med Jesu Kristi "Lov", som lyder, at vi skal hade og forsage verden, er ifølge Grundtvig, at denne lov skal virkeliggøres og holdes (GPV III, 190). Den "Velsignelse", som de kristne efterstræber, følger ikke af, at loven blot bliver forkyndt, men kun efter, at den er blevet overholdt (GPV III, 191). Velsignelsen, saligheden og himlen følger ikke af kloge ord eller formaninger eller såkaldt kristelig etisk forkyndelse, men er et resultat af dyden og af den virkelige forandring, som dermed sker med det kristne menneske. Velsignelsen følger, når de kristne realiserer og virkeliggør dyden (GPV III, 191). Dyden udvikles ved, at de spæde begynder at inddrikke modermælken. Dyden er de egenskaber og kvaliteter, som de kristne - der er lemmer på Jesu Kristi legeme lærer af deres mester. De kristne lærer efterhånden i en slags mesterlære "at kundgiøre Hans Dyder" (GPV III, 191; jf. GPV II, 296; GPV VI, 298). Kun ved at leve i det virkelige samvær med mesteren Jesus Kristus kan de - som er hans elever - erhverve sig hans "Aand og Sindelag" (GPV III, 191).

Dyden indlæres således kun hen ad vejen, og kun hvis vi lever i det nære kristelige fællesskab i den lille flok, som vandrer tværs gennem verden med al dens forfølgelse, spot og angreb (GPV III, 191). Grundtvig sammenfatter sin kritik af den fremherskende kristelige etik i det følgende spørgsmål. Grundtvigs tanke er, at dyden ikke er noget, som mennesket bare ejer eller ikke ejer på en statisk måde. Dyden lærer vi på samme måde som det lille barn, der ved sin spæde begyndelse ikke ejer megen forstand, kraft eller evne (fx GPV VI, 270; GPV VII, 277; GPV I, 165; GPV II, 396). Vi er ikke bare født som mennesker, men også født til at blive stadigt mere fuldvoksne mennesker:

saa vi kiendelig kan voxe og give et godt Eksempel og tilstoppe Bagtalernes [dvs. de vise og de skriftkloge] Munde med det Spørgsmaal, om hos dem Børnene ere ligesaa besindige, stærke og faste som de Voxne (GPV III, 191). 


\section{Kærligheden og dyden}

I en prædiken i julen 1845 kommer Grundtvig igen ind på sammenhængen mellem dyden og kærligheden ("Jule-Søndag 1845"). Han prædiker over evangeliet om Maria, Jesusbarnet, Josef, Simeon og Anna i templet. Denne lille forsamling er en "Lignelse" om den "lille Flok", "de Helliges Samfund", Jesu Kristi "Venner" eller den lille kristne menighed på jorden. Grundtvig nævner - som afslutning på sin prædiken - at han har fået åbenbaret denne fortolkning i en direkte meddelelse fra Herren, og hele denne tolkning af evangelieteksten er tydeligt nok meget vigtig for Grundtvig i hans forklaring af den sande kristendom. Den lille forsamling i templet er netop en meget lille flok og derfor et godt, sandt og levende billede på Jesu Kristi menighed. Grundtvig udlægger fortællingen som en slags allegori. Maria, som bærer og har født barnet, er "Troen", Simeon er "Haabet", og den ældgamle Anna er "Kiærligheden". Også "Verdens Viisdom" taler meget om håbet og kærligheden, men verden har ikke nogen sand kristelig forståelse af disse begreber:

som vi alle veed, i Verden afbildes Haabet og Kiærligheden altid i blomstrende Ungdom, og blændende Deilighed (...) at den [Verdens Viisdom] saaledes udelukkende afbilder sit Haab og sin Kiærlighed, der aldrig blive gamle og forlyste kun ved Blændværk ("Jule-Søndag $1845 ")$.

For verden er håb og kærlighed kun ungdommelige følelser. Disse følelser er så at sige naturlige livsytringer og ikke resultat af en læring, udvikling, opdragelse eller modning. Herimod stiller Grundtvig den sande kristelige opfattelse af håbet og kærligheden, der fødes i det kristne menneske og som langsomt modnes og vokser i styrke, jo ældre man bliver og jo mere "voxen" man bliver "i Herren". Især kærligheden kommer ifølge Grundtvigs tankegang tilsyneladende først med årene. Hans tanke er, at kærligheden er noget, som på en eller anden måde vokser frem $i$ en slags organisk proces eller læreproces. Til sidst $\mathrm{i}$ sin prædiken nævner Grundtvig således, at Josef, som er Jesu "Pleiefader", er helt nødvendig for, at det lille Jesus-barn kan modnes og vokse op og blive en voksen mand. Modningen af sønnen sker kun i et vist samfund med en fader - her i tilfældet af en "Pleiefader". Håbet og kærligheden er således to udtryk for "Dyden"; noget, som en nykommer kan lære, hvis han lever sammen med en mester. Dyden eller kærligheden er ifølge Grundtvig således hverken blot en beslutning eller - som "Verden" tror - en følelse, et spontant livsudtryk eller et indfald. Dyden og kærligheden er heller ikke noget, som blot er en beslutning. Dyden såsom håbet og kærligheden er $\mathrm{i}$ stedet noget, som gradvist vokser frem efter naturlige love. Efter- 
hånden som processen og denne læring skrider frem, bliver de to dyder - håbet og kærligheden - "ikke blot (...) gamle, men blive renere, ædlere og klarere, altsaa skiønnere i Guds Øine, jo mere de ældes" (“Jule-Søndag 1845"). Kort sagt: Dyden er det, som er skønt og elskeligt i Guds og i mesterens øjne.

Grundtvig drager i denne prædiken et skarpt skel mellem den naturlige kærlighed ude i verden eller den kærlighed, som "Verden" taler om, og den sande kristelige eller "den himmelske Kiærlighed" ("Jule-Søndag 1845"). Den himmelske kærlighed er et fænomen, som vokser og forøges i løbet af historien eller i løbet af tiden, hvorimod den kærlighed, som "Verden" taler om, synes at blive mindre tydelig eller aftage i styrke med årene. Efterhånden som tiden går, og manden bliver ældre, sker der det, at "den himmelske Kiærlighed", som er en "Alter-Ild", i stigende grad blusser og flammer op i høje luer. Grundtvig beskriver på den måde, hvordan "Dyden" efterhånden blusser op eller - som han siger i denne prædiken - hvordan "Christus bliver fuldvoxen" i menigheden.

\section{Dyden, barnet og vaksten}

I prædikenen fra julen 1845 beskriver Grundtvig også, hvad der er karakteristisk for barnet. Begreber som børn og barn spiller en afgørende rolle i Grundtvigs prædikener. Han bruger disse begreber på en dobbelt måde - dels om børn i en bogstavelig forstand og dels om dem, som er "Børn i Herren", dvs. om dem, som netop er kommet ind i Herrens menighed og som derfor ikke er kommet langt på saliggørelsens vej. I den nævnte prædiken fra julen 1845 ("Jule-Søndag 1845") karakteriserer Grundtvig barnet ved en række egenskaber: Børn er "fattige", "aandløse", "afmægtige" og "foragtede". Barnet er "uændset", "ubevidst" og "magtesløst". Grundtvig udtrykker ofte i sine prædikener denne opfattelse af barnet eller af det lille barn, der skal ud på saliggørelsens og dydens lange vej (fx $G P V$ VI, 270; $G P V$ VII, 277; GPV I, 165; GPV II, 396; GPV VI, 14). Tanken om den "guddommelige Væxt" er vigtig i Grundtvigs Vartov-prædikener 1839-49, og han kæder den sammen med en vækst i dyden (fx $G P V$ VI, 305; GPV III, 272; GPV VI, 60; GPV VI, 104; GPV V, 314; $G P V$ II, 60; GPV III, 141, "Onsdag 3die Decber 1845", "Skiærthorsdag 1849 "). Barnet vokser stadigt, og vi skal ikke tage det lille barn som et godt eller sandt billede på det at være et kristent menneske.

Grundtvigs opfattelse af barnet hænger således sammen med hans dydsskema. Hos barnet finder vi ikke nogen stor dyd, evne eller kraft af den enkle grund, at udviklingen af dyden foregår på en lang rejse, hvor porten er snæver, vejen smal, anstødsstenene mange og udfor- 
dringerne og modstanden fra verden overvældende (fx $G P V$ III, 281; $G P V$ III, 211; GPV III, 349: GPV III, 284; GPV VII, 283; "19de Søndag efter Trefoldighed 1849").

Og see vi nu først, som vi maae, paa Herrens Moder, Marie, hvorledes skulde vi da kunne tænke os et synligt Billede af Troen i vort Hjerte, ligere end hun ("Jule-Søndag 1845").

Grundtvigs prædiken fra julen 1845 er også interessant, fordi den viser en opfattelse af forholdet mellem tro, håb og kærlighed og sætter disse tre størrelser i forhold til "Dyden". I Grundtvigs udlægning af fortællingen er Maria et billede på "Troen", men i hans fremstilling af tro, håb og kærlighed er kærligheden og håbet tydeligt nok overordnet troen. Maria er den, som har født barnet Jesus Kristus - men i og med, at hun symboliserer troen og kun troen, er hun i Grundtvigs prædiken egentlig ikke kommet så langt på saliggørelsens vej. På den vej er Simeon og især Anna tydeligt nok nået meget videre. Grundtvig fremhæver da også netop kærligheden og håbet som kristelige dyder. Han nævner intet sted $\mathrm{i}$ denne prædiken troen som en kristelig dyd. Derimod synes hans tankegang at være, at de kristelige dyder vokser ud af troen, som er den oprindelige tilstand hos begynderen eller nykommeren i Jesu Kristi menighed. Maria er mere en forudsætning for udviklingen af dyden end forbundet med dyden i sig selv.

\section{Frelsen og dyden}

I en prædiken fastebehandler Grundtvig temaet om "al menneskelig Dyds Ufuldkommenhed" ("Midfaste-Søndag 1846 Aftensang"). Teksten til denne prædiken er fra Galaterbrevet, hvor Paulus taler om de kristne i Galatien, som er faldet fra deres første rette kristelige tro, og som i nogen grad er vendt tilbage til deres gamle jødedom. Men som det tydeligt fremgår af Grundtvigs prædiken, taler han mest om opfattelsen af forholdet mellem loven og evangeliet hos nogle af samtidens teologer:

Da lod de [galaterne] sig let overtale til at dele deres Hjerte mellem Loven og Evangelium og saaledes bygge deres Saligheds Haab deels paa Lovens Opfyldelse (...) og deels paa Evangeliet som en Trøst over al menneskelig Dyds Ufuldkommenhed, og vi veed sagtens at det gaaer ligedan med Mange i vore Dage ("Midfaste-Søndag 1846 Aftensang").

Denne teologiske og kristelige opfattelse er ifølge Grundtvig både naiv og misforstået. Når han her siger, at galaterne til sidst fandt sig en "Trøst" i evangeliet, er det ment på en negativ måde. Loven lyder, at vi skal elske Gud og næsten, og denne lov skal opfyldes og holdes. Vi 
behøver ikke engang at læse om en sådan lov i Bibelen, for den er skrevet i alle menneskers hjerte: "skrevet i vort Hjerte, bevidnet af vor Samvittighed, indlysende for vor Forstand" ("Midfaste-Søndag 1846 Aftensang"). Denne lov er "Naturens Lov", som er helt indlysende og som ikke kræver noget andet bevis. Denne lov behøver vi ikke høre fra en fremmed eller højere magt, for den kan vi ifølge Grundtvig sige os selv. "Den er hellig og uforkrænkelig og er paa ingen Maade Christus fremmed, er hans egen Lov, fordi han er Sandheden og det Lys, som oplyser hvert Menneske" ("Midfaste-Søndag 1846 Aftensang").

Dyden og dens indhold er for Grundtvig noget, som er indlysende og selvfølgeligt. Dyden er det mål, som alle mennesker naturligt og helt af sig selv kan indse. Grundtvigs pointe er, at uden dydens erhvervelse eller uden en virkelig forandring, udvikling eller forbedring af mennesket kan vi umuligt blive frelst. Alle mennesker kan sikkert indse, at vores dyd lige nu ikke er tilstrækkelig, eller at den er ufuldkommen til at opnå frelse fra Gud. Men Grundtvigs centrale tese i denne prædiken er, at vi ikke kan frelses uden, at vi i forvejen har erhvervet os denne dyd, og at den menneskelige dyd, som lige nu måske kan forekomme meget ufuldkommen, skal udvikles og forøges med tiden og i løbet af en kristelig vækst. Grundtvig fortsætter: "Af Lovens Gierninger kan ingen retfærdiggiøres" ("Midfaste-Søndag 1846 Aftensang"). Grundtvigs mening er, at den kærlighed, som loven foreskriver, i allerhøjeste grad skal opfyldes og virkeliggøres, men at dette ikke kan ske ved den type kristendom eller etik, som vi finder beskrevet i Galaterbrevet med de frafaldne galatere, og som Grundtvig ser eksemplificeret i samtidens kantiansk inspirerede etik og teologi.

Intet menneske kan på egen hånd eller ved egne kræfter eller alene uden som et medlem af et åndeligt samfund opfylde loven. Men loven kan i høj grad ifølge Grundtvigs prædiken opfyldes, og vi kan komme til at leve i dyden og kærligheden. Det sker ved, at vi indgår i og bliver deltagere i Jesu Kristi menighed, "annamme[r] Guds Aand" og begynder at "vandre [udvikle os] (...) ikke efter Kiødet men efter Aanden, hvis Frugter netop er hvad Loven kræver" ("Midfaste-Søndag 1846 Aftensang"). Grundtvig afviser den teologi og etik, som han finder i samtiden, der opfatter loven som en almen regel, som mennesket med sin personlige vilje skal adlyde - helt uanset, om det pågældende menneske er kristent eller ej. Uden for den kristne menighed er en sådan dydens erhvervelse ifølge Grundtvig ikke mulig, men inden i den lille flok er denne dydens erhvervelse og menneskets helliggørelse i høj grad mulig.

I slutningen af denne prædiken opstiller Grundtvig to typer af kristelig moralopfattelse: Den første, som ifølge Grundtvig er den etik, som prædikes ude $\mathrm{i}$ verden, er præget af trældom, ufrihed, frygt, 
magtesløshed, et naivt håb om frelse på trods af en manglende godhed og dyd og en overfladisk overholdelse af etiske regler eller med Grundtvigs bibelske udtryk: en "Øientjeneste" (jf. GPV VII, 241). De mennesker, som lever ude i verden, lever i et naivt håb om, at Gud vil frelse dem på trods af, at de ikke har erhvervet sig nogen dyd eller godhed eller har gjort noget fremskridt på helliggørelsens vej. Grundtvig skildrer dette såkaldte kristelige håb som et eksempel på ønsketænkning, idet disse mennesker ikke har noget grundlag for at tro på opfyldelsen af det, som de håber på.

Den anden form for etik, som er Grundtvigs egen opfattelse, er bestemt af de modsatte begreber, nemlig frihed, stolthed, glæde, en følelse af udsigt til frelsen og himmerige, en berettiget tillid, et berettiget håb i kraft af en erhvervelse i "Børnelydighed" af dyden i et virkeligt samfund med Kristus og med Faderen. Det fremkalder en naturlig og begrundet forventning om Guds frelse og om vores indgang i himmeriget eller det, som Grundtvig kalder de kristnes "Børneret" ("Midfaste-Søndag 1846 Aftensang", jf. også fx GPV VII, 241). Efter Grundtvigs opfattelse er "Dyden" noget helt andet end en blind lydighed mod visse regler, som blot vil gøre de kristne til ufri trælle, der ikke handler ud af deres eget hjerte (jf. også GPV III, 358).

\section{Evangeliet og dyden}

Temaet for en af Grundtvigs prædikener fra 1849 er også dyden og forholdet mellem dyden og evangeliet ("19de Søndag efter Trefoldighed 1849"). Den ægte og sande kristendom er at forkynde syndernes forladelse, og det er, hvad Grundtvig selv mener, at han gør, men en sådan prædiken kan bestemt misforstås:

Mange har jo vist nok meent, og mange mener endnu, at vi giør ilde $\mathrm{i}$ klart og aabenbart at forkynde og bekræfte dette glædelige Budskab om Syndsforladelse og Salighed for alle dem som af Hjertet troe paa Vorherre Jesus Christus, da det er let at forudsee og stadfæstes alt af lang Erfaring, at mange vil beraabe sig derpaa til Undskyldning for al deres Udyd og Ugudelighed ("19de Søndag efter Trefoldighed 1849").

Grundtvig kommer her ind på den anklage, der ifølge hans prædikener ofte bliver rettet imod ham: at hans prædiken om syndernes forladelse misbruges af de ugudelige og udydige som en undskyldning for blot at fremture i deres synder. Forkyndelsen af evangeliet synes altså at svække lysten til gøre dydens gerninger. Men de rationalistiske prædikanter, som fremturer med disse anklager, har ifølge Grundtvig misforstået sagen. For det første tilsiges syndernes forladelse kun til de mennesker, som har en tro, som er "af Hjertet". For det andet kræver denne tro en virkelig "Omvendelse", hvor mennesket vender sig bort 
fra sit hidtidige syndige liv ("19de Søndag efter Trefoldighed 1849”). Hvis synderen misbruger evangeliet "til syndig Sikkerhed", vil han "opdynge sig Vrede paa Vredens og Guds retfærdige Doms Aabenbarelses Dag" ("19de Søndag efter Trefoldighed 1849"). Evangeliets budskab om "Syndsforladelse og Salighed" betyder ikke, at det menneske, som modtager dette budskab, allerede er blevet frelst, fuldendt eller saligt. Evangeliet om syndernes forladelse betyder ifølge Grundtvigs prædiken, at det er blevet realt muligt for det menneske langsomt og gradvist at vokse ud af syndigheden og ud af dets "Udyd og Ugudelighed" og ind i dyden og godheden ("19de Søndag efter Trefoldighed 1849").

Der, hvor nogle af verdens prædikanter har taget fejl, er især på to områder: De mener slet ikke, at synden skal fjernes eller udryddes, men kun tilgives. Og de mener slet ikke, at det er muligt for nogen hverken for Gud eller for mennesker - at fjerne synden fra mennesket eller menneskelivet. De tager ifølge Grundtvig helt fejl, når de anser syndigheden for et evigt eller uforanderligt menneskeligt vilkår. Med hensyn til retfærdiggørelsen og på "Saliggiørelsens Vei" skal man passe på at gå på den lige smalle vej og "tage sig i Agt for at vige derfra til høire eller venstre" ("19de Søndag efter Trefoldighed 1849"). De to falske sider, som man skal undgå, er dels en naiv tro på, at Gud vil frelse mennesket, uanset om det menneske er værdigt eller uværdigt til frelsen, og dels at tro, at man skal erhverve sin egen dyd og retfærdighed helt med egne kræfter og med sin egen vilje og uden for ethvert fællesskab med en levende mester. Intet menneske kommer i himmerige uden at have erhvervet sig dyden og godheden, og derfor bliver vi aldrig frelst uden, at vi - som Grundtvig gentager hele fire gange i denne prædiken - "stræber alvorlig":

saa derimod er intet andet Raad end det, vor guddommelige Mester selv gav sine Disipler, da de spurgde ham: om det kun er faa, som blive salige, thi da svarede han hverken ja eller nej, men sagde kun: stræber alvorlig! Thi mange skal forgiæves søge at komme ind, Veien er smal og Porten snever, som fører til Livet ("19de Søndag efter Trefoldighed 1849").

Helliggørelsen foregår som en gradvis proces i det nære fællesskab med en mester, som er virkeligt til stede. Mesteren inkarnerer alle dyder eller selve dyden (fx $G P V$ II, 307; $G P V$ II, 292; $G P V$ II, 298; $G P V$ I, 64; $G P V$ VI, 151; GPV II, 259). At Kristus er død for vore synder, betyder ikke, at vi allerede er kommet ud af vores "Udyd og Ugudelighed". Det betyder, at det er blevet realt muligt for os - under visse bestemte vilkår - gradvist at komme ud af vores "Udyd og Ugudelighed". Gud lader sig ikke spotte. Dette udtryk gentages et overvældende antal gange i Grundtvigs prædikener (fx $G P V$ VII, 287; 
$G P V$ I, 76; $G P V$ VI, 299; $G P V$ VII, 221; GPV VII, 210; $G P V$ V, 166, "Pindse-Mandag 1848"). Hvis de kristne tror, at de har fået Guds frelse uden nogen som helst slags forbedring eller vækst i dyden, spotter de Gud og hans evangelium og nedkalder sig hans vrede på dommens dag:

det er gudsbespotteligt at tænke, at vi kunde narre os Syndsforladelse og Salighed til, fordi den himmelske Fader er saa eiegod, at han ikke blot vil skjule vore Synder og skiænke os det evige Liv, naar [hvis blot] vi vil troe paa Hans eenbaarne Søn ("19de Søndag efter Trefoldighed 1849").

Grundtvigs prædiken indeholder en meget skarp afvisning af en kristendom, som på den måde kun prædiker syndernes forladelse. Vi skal ikke ifølge Grundtvig bilde os ind, at Gud blot vil "komme vor Skrøbelighed til Hjælp", hvis vi ikke omvender os og forlader verden og vores egen "Udyd og Ugudelighed". Vi skal ikke bilde os ind, at Gud blot "som en Moder sukker for sit elskede Barns Frelse fra Døden” (!) ("19de Søndag efter Trefoldighed 1849”). Hensigten med evangeliet er ikke, at vi skal give op på dydens lange vej. Tværtom er hensigten, at det skal blive realt muligt for mennesket at komme ud af sin nuværende elendighed og gå hele vejen gennem dydens lange og trange vej,

saa, uagtet Gud-Fader i alle Maader kommer os tilforn [i møde] med sin Kiærlighed og Barmhjertighed (...), saa er dog Veien ligefuldt smal og Porten snever, og Anstødsstenene mange, saa selv de Udvalgte skulde forføres om det var mueligt ("19de Søndag efter Trefoldighed 1849").

\section{Én dyd eller mange dyder?}

Grundtvig behandler spørgsmålet om, hvorvidt der findes én eller flere dyder i en prædiken fra 1849 (“Allehelgens-Dag 1849"). Det kristelige liv er et "Levnetsløb" eller en løbebane, hvor de kristne gradvist stiger opad mod lyset. Det kristne menneske udvikler sig "fra Klarhed til Klarhed", indtil det er blevet en af Guds "Helgene", der skinner som solen. Disciplen bliver efterhånden som sin mester, der er Kristus. Meningen med at være en discipel er, at man skal blive som sin mester. Bogstaven ihjelslår, men ånden gør levende. Den godhed og den dyd, som det kristne menneske skal erhverve sig, kan ikke ifølge Grundtvigs prædiken nedskrives med ord og sætninger i regler eller formelle udtryk. Det gælder også "Herrens Bjergprædiken", som er blevet misforstået, og som skal forstås på en "christelig" måde.

Disciplen lever sammen med sin mester, og disciplen lærer godheden og dygtigheden ved at se på sin mesters gode gerninger. De 
"aandelige Ting (...) forstaaer ingen Læser (...) af sig selv, men maa undervises af Aanden" (“Allehelgens-Dag 1849”). De gerninger, som mesteren, Kristus, nu gør i sit åndelige liv, er langt større end dem, han gjorde i sine kødelige dage. Mesteren sætter ved sin levende aktivitet standarden for det, som er det gode, og for det, som er disciplenes mål. Eleven skal gå i mesterens fodspor og "med Glæde følge Hans Vei paa Jorden og Hans Saliggiørelses-Orden" ("Allehelgens-Dag 1849”). Eleven saliggøres hen ad vejen ved at erhverve sig mesterens dyder, og enhver sådan erhvervelse foregår $\mathrm{i}$ en naturlig orden og rækkefølge. Disciplene får så meget, som de kan bære, og de vokser i dyden og stiger opad imod himlen på den måde, der er realt mulig. I en langvarig proces lærer disciplen at blive som sin mester og gøre - ikke sine egne gerninger - men mesterens gerninger. Det, som disciplen lærer, er ifølge Grundtvigs prædiken de "christelige Dyder" ("Allehelgens-Dag 1849"). Formålet med disse dyder er disciplens "Fuldkommenhed". En lignende tankegang om Kristi "Dyder" findes også fx i "Paaske-Søndag 1846”. På spørgsmålet, om der er én eller mange dyder, som disciplen skal lære, svarer Grundtvig:

det var ogsaa først ved Morten Luthers Lyskamp (...) vi atter lærde at forstaae Herrens Bjergprædiken christelig, saa vi hverken indbilder os der er meer end een Salighed, eller at man virkelig, hjertelig kan blive fuldkommen i een Dyd uden at være det i dem alle, ligesom Herren selv (“Allehelgens-Dag 1849").

Kristus er fuldendt $\mathrm{i}$ alle dyder, fordi alle dyder $\mathrm{i}$ virkeligheden er én og den samme dyd. Grundtvig opregner syv "christelige Dyder", som fører mennesket til "Fuldkommenhed", og som Jesus erhvervede sig og ejede til fuldkommenhed, nemlig at være "barmhjertig", "reen", "hellig", "nidkiær", "sanddru", "fredsommelig" og "sagtmodig og ydmyg af Hjertet" ("Allehelgens-Dag 1849"). Disciplene skal "blive som deres Mester", og det kristne menneske skal hen ad vejen erhverve sig disse syv dyder, som dybest set er én og den samme dyd (“Allehelgens-Dag 1849").

\section{Dyden og karakteren}

En tilsvarende tankegang om de kristelige dyder finder man i en anden prædiken fra 1849 (“2den Helligtrekonger-Søndag 1849”), hvor Grundtvig prædiker over brylluppet i Kana. Forvandlingen af vand til vin er et billede på forvandlingen af det kristne menneskes karakter. Da Jesus sidder sammen med sin mor ved brylluppet i Kana, har han ifølge Grundtvigs prædiken nået "sin Vexts Fylde" ("2den Helligtrekonger-Søndag 1849”). Ligesom det kristne menneske gennemløber en åndelig udvikling, gennemløb den historiske Jesus den samme art af 
åndelig udvikling. Den åndelige vækst er en erhvervelse af de kristelige dyder, og den kan hos de kristne kun ske i et levende fællesskab med "den guddommelige Læremester" ("2den Helligtrekonger-Søndag 1849”). Disciplene lærer efterhånden det, som mesteren allerede har lært. I løbet af processen lærer disciplene at "aabenbare" mesterens dyder ("2den Helligtrekonger-Søndag 1849"), og dermed menes tydeligt nok at udvise og eftergøre dem:

saa Spørgsmaalet er kun, om vi med Ham, med vor Herre og Frelser, besjælede af hans Aand og overvundne af hans Kiærlighed, kan træde i hans Fodspor og aabenbare hans Dyder ("2den HelligtrekongerSøndag 1849").

Forvandlingen af det kristne menneskes indre karakter er "at rense det Indvortes":

men alle stræbe, efter Herrens Formaning først at rense det Indvortes, visse paa, at efter Hans Ord bliver da ogsaa det Udvortes reent, hvordan det saa end betragtes og bedømmes af Verden (" 2 den Helligtrekonger-Søndag 1849”).

Det menneske, som kommer ind i fællesskabet med mesteren, er som en nykommer præget af "al Kiøds og Aands Besmittelse" ("2den Helligtrekonger-Søndag 1849"). Det naturlige menneskes karakter og indvortes liv ejer ingen umiddelbar godhed i sig selv, og det er ifølge Grundtvigs prædiken forurenet og besmittet. Når det indvortes er blevet rent, bliver alt det udvortes og alle gerningerne også rene. Gerningerne kommer af "det Indvortes", altså af den indre dyd eller karakter.

Det er den indvortes tilstand - dyden eller karakteren inden i manden - som bestemmer og definerer mandens og hans gerningers godhed. Ingen gode frugter kan komme fra et dårligt træ. Forandringen eller "Renselsen" af "det Indvortes" sker imidlertid ikke på én gang, men gennem en lang proces. Den resulterer $i$, at det kristne menneske holder Guds "Befalinger med Lyst" og "Glæde", og den voksende dyd i det kristne menneske giver det motivation, evne og magt - ja, nærmest en almagt: "vi formaaer alt i Jesus Christus, som giør os stærke" ("2den Helligtrekonger-Søndag 1849"). Fællesskabet og samværet med mesteren - "Herrens virkelige Nærværelse" - giver de sande kristne den "vidunderlige Magt og Styrke", som ligger i den "Troe" og "Kiærlighed", som binder dette fællesskab sammen ("2den Helligtrekonger-Søndag 1849"). Dyden gør det dydige menneske kompetent, stærkt og mægtigt, så det "formaaer alt". Evangeliet betyder ingenlunde en afskaffelse af "Guds-Loven", men det virkelige samfund med mesteren gør en opfyldelse af "Kiærligheds-Budene" på én gang både nødvendig, naturlig og realt mulig - også derved, at der opstår en ny 
vilje, lyst og motivation hos de sande kristne. De gode frugter kommer af sig selv af det gode træ.

I fællesskabet med mesteren og ved direkte at erfare og opleve, "at Herren giør Tegn" som en levende mester sammen med sine elever og lærlinge, forvandler mennesket sin karakter til en ny natur af "Kraft", "Fylde" og "Glæde": "saa det Udvortes som et Speil af det Indvortes, bliver ogsaa reent og klart, hele det christelige Liv og Levnet udvikler sig af Christi Kiærlighed i Jesu Christi Aand og Smag!" ("2den Helligtrekonger-Søndag 1849"). "Liv" er den nye type af liv, som er blevet realt muligt for det menneske, som er begyndt på dydens lange vej $\mathrm{i}$ det kristelige fællesskab. "Levnet" betegner i Grundtvigs tekster selve forløbet, processen, som det enkelte menneske gennemgår og som består af de begivenheder og forandringer, der sker hen ad vejen.

\section{Kritikken af samtidens dydsopfattelse}

I en prædiken fra 1844 taler Grundtvig om sammenhængen mellem Kristus og dyden og om den opfattelse af dyden, som Grundtvig finder hos "de Lærde og Kloge" (GPV VI, 395: "24de Trinitatis-Søndag 1844", teksten er Matt 9,18-26). ${ }^{4}$ Grundtvig afviser her en Jesusopfattelse og dydsopfattelse, som han finder udbredt hos samtidens teologer. De gør nemlig kun Kristus til en "Helgen" og til et ideal, som de kristne skal stræbe efter at efterligne. Men Kristus og hans storhed bevises ikke ved, at han er et stort dydens mønster, men ved, at dyden hos de sande kristne vokser, når de lever $\mathrm{i}$ et samfund med ham. Kristus er ikke først og fremmest vigtig på grund af sin høje dyd, men fordi han har fået et "Vidnesbyrd" af "Faderen" (GPV VI, 395). Dette vidnesbyrd er i Grundtvigs prædiken en vis magt, virkning og virkelighed. Den dyd, som Kristus ejer, og den dyd, som de sande kristne kan udvikle og erhverve sig, er en virkelig og mærkbar forandring. Gud har åbenbaret sin visdom for "de Umyndige" og "de Vankundige" og skjult den for "de Lærde og Kloge" (GPV VI, 395).

${ }^{4}$ Thodberg (2007, 296-299) Thodberg kalder denne prædiken for "en af de mest inspirerende prædikener i kirkeåret 1843-44" (Thodberg 2007, 296). Ifølge Thodberg har denne prædiken sammenhæng med Grundtvigs salme "Med den Eenbaarnes Herlighed" (DS02 143), som antageligt er forfattet i 1844, men Grundtvigs synspunkter i prædikenen bliver stærkt afsvækket i salmen. "Kan det tænkes, at Grundtvig i salmen har neddæmpet polemikken i prædikenen, så den bedre kunne passe ind i det bredkirkelige Prøvehefte?" (Thodberg 2007, 299). Thodberg refererer her til det tillæg til salmebogen, som var under udarbejdelse i 1844, men Thodbergs synspunkter om forholdet mellem Grundtvigs prædikener og hans salmer synes at være særdeles interessante. Peger Thodberg på en generel tendens? 
Den voksende dyd, retfærdighed og kærlighed, der følger af at være et medlem af Guds sande menighed, er noget, som kan "kiendes", ses og erfares af alle menighedens medlemmer og ikke mindst af de mest "Vankundige" og "Umyndige" ( $G P V$ VI, 395).

Dyden gør en forskel. Grundtvig bestemmer dyden som noget, der eksisterer i den virkelige verden, som vi sanser og erfarer, og som erhverves i et vist fællesskab. På den måde afviser Grundtvig en dydsteori hos "de Lærde og Kloge", der tilsyneladende er en slags kantianere, hvor dyden mest bliver defineret ved regler og normer. Dydens bestemmelse og indhold er ikke almene sætninger eller formuleringer, som vi kan læse i en bog eller nedskrive på et stykke papir. Grundtvig ser dyden som en konkret forholden sig til en konkret situation ud fra visse konkrete forudsætninger, som ikke kan kodificeres i nogen abstrakt formulering. Grundtvigs tekst udtrykker på den måde et næsten "klassisk" skema om dyden, som kan minde om dydsbegrebet i antikkens Grækenland. Dyden er det, som den dydige mand gør.

\section{Forvandlingen af karakteren og hjertet}

I en prædiken fra 1841 taler Grundtvig om forholdet mellem dyden og det kristelige liv (GPV II, 277-281: "4de Trinitatis Søndag 1841”). Grundtvig prædiker over bibelstedet "Værer barmhjertige ligesom eders Fader er barmhjertig" (GPV II, 278). Grundtvig henviser her til de "Dydens Prædikanter", som ifølge hans opfattelse har og har haft så stort et ord i den kristne kirke. Når Grundtvig på den måde omtaler "Dydens Prædikanter", kunne man få det indtryk, at han tager afstand fra enhver tale om den kristelige dyd, men det er tydeligt nok ikke tilfældet:

Deri havde nemlig Dydens Prædikanter (...) ingenlunde Uret, at de sagde, det var dog baade først og sidst inderlig Barmhjertighed og virksom Menneske-Kiærlighed, hvorpaa det kom an i Salighedens Sag, saa det var kun Tant med al den Tro og Christendom, som ikke førde dertil, nei, heri havde de fuldkommen Ret og kunde aldrig paastaae det saa fuldt og fast, at Vorherre Jesus Christus ikke udtrykde det endnu langt klarere og indskærpede det langt ivrigere (GPV II, 278).

Grundtvig er fuldstændigt enig med dydens prædikanter om, at der kun gives frelse i dydens erhvervelse. Spørgsmålet gælder vejen til denne nødvendige dyd. Grundtvigs modparter og deres forgængere i det 18. århundrede er "Disipler, som vilde være klogere end deres Mester" (GPV II, 279). Dyden erhverves ikke ved at antage Jesus som et højt etisk ideal, men som nævnt tidligere ved, at de kristne lærer dyden i en praksis sammen med den levende Kristus. Dette er "den jævneste Vei 
til den Høiestes Boliger” og den "jævneste” vej til dyden (GPV II, 278).

I denne prædiken sammenkæder Grundtvig dyden og kærligheden med "Hjertet" (GPV II, 279, jf. GPV I, 346). Dyden består i, at der sker en forandring af menneskets "Hjerte". Dyden er de gerninger, ord og følelser, som kommer ud af hjertet. Hvis dyden kun defineres som en lydighed eller efterlevelse af blotte regler, så bliver dyden og godheden noget rent "udvortes" (GPV II, 279). Gud ser på hjertet, og Gud "forlanger Hjertet heelt og holdent, forlanger al vor Kiærlighed" (GPV II, 279). Det, som Gud kræver, er ikke - som "Dydens Prædikanter" måske tror - en efterlevelse af et abstrakt eller uopnåeligt ideal. Det, som Gud forlanger, er noget, som rent faktisk finder sted og virkeliggøres på dydens trange, men jævne vej. Kærligheden er de gerninger, der kommer ud af det nye "Hjerte", som er på vandring på dydens vej, og som er i færd med at erhverve sig en stadigt højere dyd. Dydens vej er ifølge Grundtvigs prædiken "den jævneste Vei” af den grund, at den kan erfares af ethvert menneske, når det vel at mærke rent faktisk befinder sig på denne vej. Dydens vej er "mørk for Verdens Vise", men endog "klar for Kvinder og Børn" (GPV II, 279). Når verdens kloge filosoffer taler om dyden, er de aldeles blinde, og de falder i graven (GPV II, 279). Dyden kan ifølge Grundtvigs tekst aldrig komme ud af et blot naturligt eller ikke-omformet hjerte. Dyden kan kun komme fra menneskets "Dybheder", fra dets karakter. Godheden, dyden og kærligheden er mulig og i høj grad virkelig for dem, som lever sammen med deres mester - nemlig "for alle fromme og kiærlige Hjerter og kun for dem” (GPV II, 279).

\section{Mønsteret, mesteren og dyden}

I en prædiken fra 1844 beskriver Grundtvig Kristus som "al Fromheds og Helligheds fuldkomne Mønster" (GPV VII, 19). Kristus er "Dydens Mønster", og tanken om dette "Mønster" optræder et stort antal gange i Grundtvigs prædikener (fx $G P V$ I, 448; GPV II, 293; $G P V$ III, 39; $G P V$ II, 65; $G P V$ V, 173; $G P V$ VI, 236; $G P V$ VI, 237; $G P V$ III, 269; GPV I, 26; GPV I, 448, samt "2den Søndag efter Paaske 1846"; "17de Søndag efter Trefoldighed 1849": Kristus er "vort Mønster og vor Mester" og "17de Trefoldigheds-Søndag 1848": Kristus er "det fuldkomne Mønster til Efterligning” og “3die Advents-Søndag 1848”: "da giør vi vor Faders Gierninger, og stræber i alle Henseender at ligne Hans Førstefødte, vort Mønster”, og "2den Onsdag i Faste 1847”: “[Kristus er] et Mønster paa alle menneskelige Dyder").

Kristus er ifølge Grundtvigs prædiken i 1844 langt mere end det, som Grundtvigs modparter kan opfatte som et "Dydens Mønster". 
Kristus er herre, frelser, Guds søn og forsoner, men Kristus er bestemt også ifølge Grundtvig et "Dydens Mønster" (jf. også GPV II, 153: "5te Faste-Onsdag 1841"). Grundtvig forstår begrebet "Mønster" på to forskellige måder: Kristus er de sande kristnes "Mønster", fordi de i Kristus kan se, hvad dyden er (dens indholdsbestemmelse), og Kristus er et "Mønster", fordi han lever sammen med de kristne som en virkelig mester i et læringsfællesskab. De gerninger, som Kristus gjorde "i sit Kiøds Dage", var store og prægtige, men de gerninger, som han gør nu "i sin Aands Dage", er langt større og mægtigere (jf. $G P V$ II, $152 \mathrm{f}$.). Disciplene ser på deres mester, og de lærer at handle i hans ånd. Dyden opfatter Grundtvig som det at gøre noget i en bestemt ånd - ikke først og fremmest at gøre bestemte handlinger, som kan udtrykkes i regler eller sætninger. Den lærling, som lever og arbejder sammen med mesteren, erhverver hen ad vejen den dyd og dygtighed, som mesteren engang har erhvervet sig og nu besidder og udøver (jf. også "17de Søndag efter Trefoldighed 1849"). Meningen med at være en discipel er, at man skal blive som sin mester (fx GPV II 279, 152 f.). Når disciplen gør mesterens gerninger - altså dyden - gør han ikke præcist det samme som mesteren, men han handler ud fra et hjerte, en karakter, tilbøjelighed eller ånd, som er kommet til at ligne mesterens ånd, hjerte eller karakter (GPV II, 152 f.).

\section{De kristelige dyder}

I en prædiken fra fasten 1847 beskæftiger Grundtvig sig indgående med spørgsmålet om dyden ("2den Onsdag i Faste 1847"). Alene i denne ene prædiken bruger Grundtvig begrebet "Dyden" 17 gange og begrebet "dydig" en enkelt gang. Han udtrykker i flere prædikener (jf. tidligere) den opfattelse, at alle dyder dybest set er én og den samme dyd, men han kan også definere de enkelte kristelige dyder, og i denne prædiken fra fasten 1847 kommer han med en række formuleringer af disse dyder: "den majestætiske Høihed", den "heltemæssige Frimodighed", "Ydmyghed", den "uovervindelige Taalmodighed", "Sjælens Høihed", "den himmelske Sagtmodighed", "Hjertets Ydmyghed", "den rene, uegennyttige Kiærlighed til Gud og Næsten”, "den ligesaa guddommelige som menneskelige Kiærlighed, der sætter Livet til for sine Venner" (“2den Onsdag i Faste 1847”). Derudover definerer Grundtvig fire forskellige kristelige dyder ved at beskrive Kristus og hans dyder som en model eller et mønster for de sande kristne: (1) "han [Kristus] tav til alle Beskyldninger, hvormed han besvarede det falske Spørgsmaal om Hans Lærdom", (2) "han straffede de Uforskammede, der forgreb sig paa Hans Person", (3) "han smeltede sine 
faldne Disipler" og (4) "han bekiendte sin Ret til Thronen ved Guds høire Haand" ("2den Onsdag i Faste 1847").

Kristus viser på disse fire måder sine "Dyder", og ifølge Grundtvigs prædiken er det netop disse "Dyder", som de sande kristne skal lære ved det "Mønster", som Kristus udgør ("2den Onsdag i Faste 1847'). Beskrivelserne er altså ikke kun udredninger af, hvad den historiske Jesus gjorde og viste, men en fremstilling af selve den kristelige dyd. Sådan som Kristus optrådte, skal de kristne lære at optræde over for verden. Det er interessant, at egenskaber, der hænger sammen med styrke, magt og myndighed, spiller en fremtrædende rolle i Grundtvigs forståelse af dyden. Den dydige mand er myndig og mægtig. Alle de forskellige dyder er forenet i den ene dyd, kærligheden, som Grundtvig bestemmer på to forskellige måder: dels som "den rene, uegennyttige Kiærlighed til Gud og Næsten" og dels som "den ligesaa guddommelige som menneskelige Kiærlighed, der sætter Livet til for sine Venner" ("2den Onsdag i Faste 1847”). Dyden viser sig også i den magt og mægtighed, at man kan sætte sit liv til for sine venner. Tanken om martyriet og selvofferet spiller en vigtig rolle $i$ Grundtvigs opfattelse af dyden (jf. fx hans prædikener på 2. juledag i alle årene 1839-49). Kristus er også et dydens "Mønster" for hans "Venner" på den måde, at de skal sætte deres liv til for deres venner, som han gjorde for sine.

I sin prædiken fra 1847 beskriver Grundtvig, hvordan Kristus er de kristnes konge, og hvordan de kristne er hans folk. Kongens dyder er på den måde også folkets dyder. Folket lærer sine dyder af kongen, og uden en konge, som virkeligt besidder dyden, ville folket ikke eje nogen dyd. Som kongen er, således bliver hans folk. Indholdet af dyden er i Grundtvigs prædiken givet med selve denne relation. Dyden er at handle passende i forhold til konteksten og relationen, og dydens indhold fremgår af sig selv, når vi ser på den faktiske relation og kontekst. Dydens væsen og indhold ligger immanent og selvindlysende i det, som Grundtvig kalder for "Samfundet", nemlig relationen mellem kongen og folket. Uden en konge ville folket ikke være noget folk overhovedet, lige så lidt som en elev er elev uden en mester.

I sin prædiken fra fasten 1847 kommer Grundtvig også ind på spørgsmålet om, hvordan man lærer eller erhverver sig dyden. Det nytter ikke meget at "holde lange Lovtaler over vor Frelsers daglige Dyder" ("2den Onsdag i Faste 1847"). Begrebet "Nytte" gentages ikke færre end seks gange, og evangeliet og forkyndelsen måles ifølge Grundtvig på deres virkning og på, om resultatet er "frugtbart". Grundtvig bruger ordet "virkelig" om det, som virker. For eksempel siger han om troen: "Troen er den eneste virkelige Deltagelse". Troen er det eneste, som gør en forskel og har en virkning. En kristelig 
forkyndelse, som ikke rent faktisk bevirker en forbedring af dyden, er en stor "Daarlighed".

Thi det var ikke Apostelen Peders Mening at vi skulde holde lange Lovtaler over vor Frelsers daglige Dyder, men at vi skulde vise dem (...) thi den blotte Beskrivelse [af "Dyden"] er død og magtesløs (“2den Onsdag i Faste 1847”).

Det er ikke meningen, at vi kun skal beundre Kristus og hans dyder. Meningen er, at vi skal blive, som han er, og erhverve os hans dyder. Grundtvig forklarer udtrykket om, at vi skal "aabenbare" og "forkynde" Herrens dyder, ved, at vi skal "vise", udvise eller udøve disse dyder ("2den Onsdag i Faste 1847"). Grundtvig spørger, hvorledes vi kan lære eller erhverve os dyden, og han afviser i den forbindelse en række muligheder:

Det er nemlig kun, naar man ved Dyder blot forstaaer (...) udvortes Handlinger, at man kan tænke, Dyder lader sig meddele og forplante ved blotte Exempler (...) saa er det aldeles vist, at ikke det allermindste deraf kan enten det skiønneste Eksempel, den retfærdigste Lov eller den dydigste Tale frembringe ("2den Onsdag i Faste 1847").

Den kristne kan kun lære dyden i en form for praksis eller ved en handling eller ved at være et virksomt medlem af et samfund, en relation eller fællesskab. Det er interessant i forbindelse med Grundtvigs opfattelse af sammenhængen mellem læring, disciple, mester og fællesskab, at han fremhæver, at denne levende mester også "arbeider" med i dette praksisfællesskab (fx GPV I, 448). Han, som er de kristnes mester, mønster og lærer, er også deres medarbejder som enhver anden mester på et værksted (jf. fx GPV II, 278f, 153). Meningen er, at "Jesus Christus (...) skal (...) være os til (...) Nytte i vor Saligheds Sag” ("2den Onsdag i Faste 1847”), og det betyder ifølge Grundtvig, at vi skal lære og erhverve os dyden - nemlig den dyd og de dyder, som vi kender fra vores levende herre og mester Jesus Kristus, i hvis hus vi lever, bor og arbejder.

I samværet med denne mester og herre lærer vi de kristelige dyder, og vi får "et nyt Hjerte" ("2den Onsdag i Faste 1847"). Også denne prædiken er et godt eksempel på, at når Grundtvig taler om "Hjertet", mener han ikke kun en passiv modtagende instans i mennesket, men et aktivt og agerende element. Han synes at antage en indre karakter eller dyd. Udtrykkene, at Gud ser på "Hjertet" og at Gud forvandler "Hjertet", betyder hos Grundtvig, at Gud ser på det, som gør en forskel - nemlig den godhed, som findes i vores inderste, og at Guds hensigt og vilje er at forvandle dette "Hjerte" eller denne indre dyd eller karakter. Det "Hjerte", som de sande kristne erhverver sig, er "ligedannet efter hans [frelserens] eget" ("2den Onsdag i Faste 1847"). 
En sådan ændring af det indre menneske og af den indre dyd og karakter er ifølge Grundtvig "Alt sammen Umueligheder for vore Øine", men når Grundtvig her siger for "vore Øine", mener han tydeligt nok ikke sine egne øjne, men "Verdens" øjne. "Verden" tror, at alting er statisk og uforanderligt og evigt det samme. Verden tror ikke på en sådan forandring af den indre dyd og karakter, men de kristne, som er lemmer på det hele legeme, er ifølge Grundtvig hver dag vidner til en sådan forandring og forvandling. Hen ad vejen erfarer de kristne, at de forvandles til at blive "et helligt Eiendoms-Folk" ("2den Onsdag i Faste 1847"). Uden for det kristelige fællesskab uden en virkelig "Deltagelse" - kan en sådan forandring af det indre menneske ifølge Grundtvigs prædiken "umuelig" ske. Dyden læres i en virksomhed, hvor de forskellige agenter netop er deltagere og medarbejdere.

Derfor kaldes vor Herres Jesu Christi Lærdom et Evangelium (...) fordi hvad der er baade os og Loven og alle Engles gode Eksempel umueligt, det vil Guds Naades Ord udrette i de Troende, saa de (...) faaer Magt (...) til at ligne Guds Søn og aabenbare Hans Dyder ("2den Onsdag i Faste 1847").

Formålet med evangeliet er ikke, at disciplene kun skal beundre deres mester, og heller ikke, at de kun skal erkende, at de slet ikke har mesterens dyd. Formålet med evangeliet er, at disciplene skal blive som Kristus, deres mester ("2den Onsdag i Faste 1847"). Det kristne budskab er "evangelisk", fordi det rummer et løfte om, at de kristne skal blive forandrede og ligedannede med Kristus. Endnu har vi ikke nået målet, men vi er på vej, og når vi tænker på, hvor langt vi endnu skal gå på vejen, så "sønderknuses vi dog ingenlunde" ("2den Onsdag i Faste 1847"). Den udvikling og læring, som de sande kristne erfarer og gennemløber, er en centripetal bevægelse. Eleverne trækkes alle ind imod det samme centrum, som udgøres af ånden hos deres mester og herre.

Denne læring foregår ifølge Grundtvig et bestemt sted, som er omkranset af en "Mur". Tanken om denne "Mur", der afgrænser lærestedet og som også kaldes "Zions Mur", spiller en fremtrædende rolle i Grundtvigs læringsteori. Uden for "Zions Mur" er "Fienden”, som vil overliste og tilintetgøre de kristnes lærested og praksisfællesskab (fx GPV I, 148; GPV II, 128; GPV III, 437; "4de Helligtrekonger-Søndag 1846"; “11te Søndag efter Trefoldighed 1849”). En læring af dyden kan ifølge Grundtvig kun finde sted $i$ et defineret rum eller område sammen med et afgrænset antal deltagere, som netop lever i en virkelig relation med hinanden og til en mester. Et sted prædiker Grundtvig om "Pharisæerens Gang til Bedehuset og hans Fremgang paa Retfærdigheds Vei", og Grundtvig siger om disse farisæere: "men man 
[farisæerne] bliver dog altid deruden for, ligesom en, der gik langs med Paradisets Mur, men søgde kun forgiæves enten at overstige eller giennembryde den" (“11 te Søndag efter Trefoldighed 1849”).

Dyden er noget helt andet end "Pligter" i forhold til regler (GPV VI, 268). Dyden og kærligheden lærer vi ved, at vi holder os nær til vores mester ( $G P V$ III, 265). Grundtvigs tanker om en sådan "Herrens Skole", hvori vi lærer de kristelige dyder, spiller en særdeles fremtrædende rolle i hans prædikener 1839-49 (fx GPV I, 23f, 27, 39 f., 154, 513; GPV II, 185, 315, jf. også Grundtvigs prædiken fra 1855 trykt i Lindhardt 1974, 134). Det, som de kristne lærer i denne praksis, er ikke noget "udvortes" - såsom lydighed mod visse regler eller bud men netop en ny indre karakter, som kan blive en indre kilde, motivation og årsag til nye gode gerninger:

thi det er Herrens, ligesom det er Sandhedens Grundsætning, at først maa man virkelig være hvad man vil vise, man er, ellers er det kun Tant og Blændværk ("2den Onsdag i Faste 1847”).

Grundtvig er ikke en "pragmatisk filosof" i den betydning, som dette begreb er blevet anvendt i filosofiens historie, og Grundtvig prædiker naturligt nok ikke filosofi, når han står på prædikestolen i Vartov, selvom denne prædiken fra fasten 1847 - ligesom mange andre steder $\mathrm{i}$ hans prædikener - viser, hvordan han i sin tænkning om kærligheden og dyden går ud fra erfaringen og det konkrete levede menneskeliv.

\section{Dyden, dygtigheden, dueligheden og fortjenesten}

Grundtvigs begreb om og forståelse af dyden har sammenhæng med hans tanker om det kristne menneskes dygtighed, duelighed og evner. Når man er en fader, har man større magt, evne og kraft og derfor også et større ansvar og en anden forpligtelse over for dyden. Grundtvigs synspunkt er, at det kristne menneske ikke får større udfordringer, end det kan bære, at det kristne menneske skal leve op til de evner og den dygtighed, som det rent faktisk besidder, og at det kristne menneskes evner og dygtighed ikke er statiske, men netop dynamiske størrelser (fx $G P V$ VI, 310; GPV III, 424; GPV II, 324; GPV VII, 256; $G P V$ VI, 121; GPV II, 415; GPV V, 206; GPV III, 321; GPV VI, 307; $G P V$ VII, 249; GPV I, 30 samt “12te Trinitatis-Søndag 1848”).

I sine prædikener i Vartov sammenkæder Grundtvig en række begreber såsom dyd, retfærdighed, fortjeneste, ret, magt og ros. Grundtvig anvender udtrykket "Dyd og Retfærdighed" i sine sammenfatninger af målet for det kristelige liv ("11te Søndag efter Trefoldighed 1849”; GPV III, 256; GPV I, 41; GPV I, 513). På samme måde anvender han formlen "Fortjeneste, Dyd og Retfærdighed" (GPV III, 352). I et meget stort antal tilfælde taler Grundtvig om "den Roes", 
som det syndige menneske fattes og mangler, og som det skal erhverve sig for at komme ind i himmeriges rige (fx $G P V$ VI, 156; $G P V$ III, 80; $G P V$ III, 352; GPV V, 167; GPV III, 83, "18de Søndag efter Trefoldighed 1848"). Grundtvig taler ofte om de kristnes "Ret", og et sted taler han om det kristne menneskes "Ret til at indgaae i Himmeriges Rige" (GPV II, 295). Grundtvig synes visse steder at give udtryk for noget, som ligner et næsten "klassisk" dydsskema: Kun den dydige mand vinder livets krone, og det er vores godhed og dyd, som lukker himlen op (jf. GPV II, 295 f.). I alle disse tilfælde udtrykker Grundtvig vigtigheden af, at det kristne menneske erhverver sig eller udvikler en dyd, som dels kan gøre det muligt for mennesket at blive frelst og som dels kan gøre det værdigt til at indgå i de himmelske boliger. Den "Retfærdighed", Grundtvig taler om, identificerer han ofte med en tale om "Dyden" (fx "11 te Søndag efter Trefoldighed $1849 ")$.

\section{Sammenfatning}

Det fremgår tydeligt af Grundtvigs prædikener i Vartov, at han $\mathrm{i}$ 1840 'erne må leve med et vist dårligt rygte ude i "Verden", og at en del af verdens kritik af Grundtvigs kristendom er, at Grundtvig har glemt dyden. I en prædiken 14. søndag efter trinitatis 1839 siger Grundtvig således:

medens der sædvanlig nedregne de bitterste Bebreidelser og de haardeste Beskyldninger over os [Grundtvig og hans tilhængere], som skammelige Hyklere, eller afsindige Daarer, Mørkets Apostler, den menneskelige Naturs Forhaanere, Dyds og Viisdoms Foragtere ( $G P V$ I, 89).

Den kritik, som Grundtvig her henviser til, er interessant på flere måder. Grundtvig får siden et ganske andet image med hensyn til sit forhold til den menneskelige natur og det naturlige menneske, og Grundtvigs anskuelser med hensyn til den menneskelige natur er muligvis også anderledes i hans senere skrifter som fx Den christelige Børnelaerdom. Det problem skal ikke undersøges her. Men det er tydeligt i Grundtvigs prædikener, at i 1840 'erne er Grundtvig ikke blevet opfattet som en repræsentant for en "glad", "lys" eller "lystelig" kristendom. Grundtvig henviser mange steder i sine prædikener til, at han i samtiden opfattes som en mørkets apostel, der foragter det naturlige menneskeliv, og som på en truende måde prædiker helvede, straf og dom (fx GPV I, 89; GPV VI, 203; "Paaske-Søndag 1846").

Grundtvig anklages i det anførte citat for at foragte dyden. Ud fra en nutidig læsning af Grundtvigs prædikener fra 1839 til 1849 forekommer en sådan kritik helt misvisende. Det, som Grundtvig 
anklages for, er ifølge hans prædikener, at han blot prædiker evangeliet og derfor giver mennesker en undskyldning for ikke at gøre noget ved dyden. Det fremgår af mange steder i hans prædikener. Men det er også netop denne kritik, som Grundtvig igen og igen afviser (fx GPV I, 532; "11te Søndag efter Trefoldighed 1849"; GPV I, 236; GPV II, 223 f.; 295 f.; GPV III, 265; GPV VII, 241).

Grundtvig går ud fra et andet dydsskema end sine kritikere. Grundtvigs kritikere synes alle steder i disse prædikener at operere med et slags kantiansk dydsskema, hvor det enkelte menneske med sin vilje og fornuft skal beslutte sig for dyden. Det er denne dydsopfattelse, som Grundtvig afviser i sine prædikener, men han mener på ingen måde, at dyden er noget, som menigheden eller det kristne menneske skal foragte. Tværtom er dyden faktisk menneskets mål, "Menneske-Maalet" (Jf. fx "17de Søndag efter Trefoldighed 1849”). I den nævnte prædiken fra 1839 refererer Grundtvig til, at de vise og kloge ude i verden opfatter sig selv som "Dydsmønstre" (GPV I, 89). Grundtvig er fuldt ud enig i det synspunkt, at dyden er det, som det kristne menneske skal efterstræbe, men hans pointe er, at det kun kan ske i det levende "Samfund" sammen med mesteren - den "Mester", som selv er et "Dydens Mønster". Denne opfattelse af dyden - og af den lange og trange vej til erhvervelsen af dyden - opfatter verden som en ren "Daarskab" og som noget "forargeligt" (GPV I, 89).

Striden mellem Grundtvig og de rationalistiske teologer og prædikanter er ikke en strid om selve dydens betydning, men en strid mellem to forskellige definitioner af dyden. Hos Grundtvig finder vi i et vist omfang en klassisk opfattelse af dyden som den godhed og de gode gerninger, der naturligt udspringer af en indre karakter. Hos hans mere eller mindre kantianske modstandere finder vi - i al fald ifølge Grundtvigs gengivelse - en stærkt forkortet dydsteori, hvor væsentlige dele af den oprindelige dydsteori fra oldtiden og middelalderen er barberet væk, og hvor dyden mest er blevet et spørgsmål om en personlig beslutning eller individuel viljesakt.

I forbindelse med temaet om Grundtvig og dyden kan man stille to forskellige spørgsmål: Det første vedrører, om Grundtvig overhovedet anvender dydsbegrebet i sin forkyndelse af kristendommen, og om han anvender dydsbegrebet på en vigtig og betydningsfuld måde. Det andet spørgsmål går på, om Grundtvig formulerer sin kristendomsforståelse og sin forståelse af den kristelige kærlighed inden for rammerne af et virkeligt dydsskema. De anførte eksempler fra Grundtvigs prædikener i Vartov fra 1839 til 1849 viser, at begge spørgsmål kan besvares bekræftende.

At Grundtvig tænker $\mathrm{i}$ et virkeligt dydsskema, viser sig måske allertydeligst $\mathrm{i}$ hans modstilling af det lille barn og den fuldvoksne 
mand. Det lille barn er en nykommer i livet, og udtrykkene "Barn" og "Børn" betegner også hos Grundtvig en nykommer i Jesu Kristi menighed på jorden. En sådan nykommer eller et sådant lille "Barn" har ikke nogen stor dyd og har slet ikke nogen særlig kraft, kærlighed eller fornuft. Modpolen til dette lille "Barn" er netop den fuldvoksne mand. Hos ham finder vi en udviklet og modnet dyd - dvs. en udviklet og modnet kærlighed, visdom, mægtighed, evne, kraft og indsigt.

Det, som sker på vejen fra det lille barn til den voksne mand, er i Grundtvigs prædikener en erhvervelse af den "Roes", "Fortjeneste" og "Dyd", som de kristne nødvendigvis må have i Guds øjne og som giver dem en "Ret til at indgaae i Himmeriges Rige" (GPV II, 295). Vi skal ifølge Grundtvigs dydsskema først blive som "Børn", men det er bestemt ikke meningen, at vi skal vedblive med at være "Børn". Meningen med at være et barn er, at man kan og skal vokse sig ud af denne uudviklede tilstand. Meningen med evangeliet er at hjælpe de kristne med at komme ud af den tilstand af afmagt, hjælpeløshed, kraftløshed, uvidenhed og mørke, som kendetegner det lille barn. Det skema om barnet, som Grundtvig går ud fra i sine Vartov-prædikener, svarer meget godt til den klassiske opfattelse af barnet, som var rådende indtil det 19. og 20. århundrede, og som vi også finder tydeligt udtrykt i Paulus' breve til Galaterne og til Romerne i Det Ny Testamente.

"Dyden" bruger Grundtvig som et af sine centrale begreber. Begrebet udtrykker i Grundtvigs prædikener netop den retfærdighed og godhed, som det kristelige menneske har erhvervet sig og tilegnet sig gennem en lang vækst- og erfaringsproces. Dyden, godheden og kærligheden erhverves gennem en "Dannelse" og gennem en "HelgenDannelse" (fx GPV I, 497; GPV II, 86). Den "fuldvoxne" mand ejer dyden, og et godt eksempel på det er også, at han kan løfte den opgave at være en kriger i Herrens tjeneste. Denne krigstjeneste er ikke en opgave, som kan løftes af kvinder og børn.

Grundtvigs anvendelse af dydsbegrebet behøver ikke at være et håbløst levn fra fortiden. Dydsbegrebet er nærmest blevet udraderet fra den kirkelige forkyndelse $\mathrm{i}$ de protestantiske kirker $\mathrm{i}$ det 20. århundrede, på grund af dels kantianismens, dels den dialektiske filosofis indflydelse. I forhold hertil kan Grundtvigs tale om dyden være både væsentlig, relevant og interessant.

\section{Forkortelser}

GPV I-VII: Jette Holm et al (udg.) (2003, 2007), N. F. S. Grundtvig. Pradikener $i$ Vartov, bind 1-4 (1839-42), bind 5-8 (1842-45), København. 


\section{Litteraturliste}

\section{Varker af Grundtvig}

Holm, Jette et al (udg.) (2003, 2007), N. F. S. Grundtvig. Praedikener $i$ Vartov. Bind 1-4 (1839-42), bind 5-8 (1842-45), København

\section{Varker af andre forfattere}

Allchin, A. M. (1997), N. F. S. Grundtvig. An Introduction to His Life and Work, Aarhus.

Balslev-Clausen, Peter (1991): Det vingede ord: om N.F.S. Grundtvigs salmedigtning, Frederiksberg.

Birkelund, Regner (2008), Frihed til faelles bedste. En oppositionel stemme fra fortiden, Aarhus.

Bjerg, Svend (2002): Gud først og sidst. Grundtvigs teologi - en loesning af Den christelige Børnelardom, Frederiksberg.

Borum, Poul (1983), Digteren Grundtvig, København.

Bugge, K. E. (1965), Skolen for livet. Studier over N. F. S. Grundtvigs paedagogiske tanker, København.

Christensen, Anne-Marie S. (2008), Moderne dydsetik. Arven fra Aristoteles, København.

Darwall, Stephen (ed.) (2003), Virtue ethics, Oxford.

Elbek, Jørgen (1960), Grundtvig og de grceske salmer, København.

Fibiger, Lise Brandt (1977), "Grundtvigs væksttanke" i For sammenhoengens skyld, Aarhus, 213-246.

Gregersen, Niels Henrik (2000), "Mennesket som mikrokosmos. Grundtvigs digt om 'Menneske-Livet"' i Grundtvig-Studier 2000, København, 75103.

Grønbæk, Villiam (1951), Psykologiske tanker og teorier hos Grundtvig, København.

Hansen, Niels Buus (1997), "Mennesket i verden, verden i mennesket" i En orm - en gud. Om mennesket $i$ verden, Odense, 41-62.

Heggem, Synnøve Sakura (2000), "Grundtvigs kvinnesalmer, - kjærlighetens kjønnsbestemte sang" i Dansk Kirketidende, 152. årgang, København, 36-39, 56-61.

- (2005), Kjwrlighetens makt, maskerade og mosaikk. En lesning af N. F. S. Grundtvigs Sang-Vark til den Danske Kirke (1837), Oslo.

- (2007), "Mennesket i verden som brud" Grundtvig-Studier 2007, København, 148-167.

Høirup, Henning (1949), Grundtvigs Syn paa Tro og Erkendelse. Modsigelsens Grundsatning som teologisk Aksiom hos Grundtvig, København.

- (1983), Fra døden til livet. Grundtvigs tanker om liv og død, København.

Iversen, Hans Raun (1987), And og livsform. Husliv, folkeliv og kirkeliv hos Grundtvig og sidenhen, København.

Jensen, Erik Krebs (1977), "Hjertets gudbilledlighed" i For sammenhoengens skyld, Aarhus, 65-96. 
Jonas, Uffe (2007), "Kvinde-Evangeliet: Om Grundtvigs mandebilleder og kvindesyner" Grundtvig-Studier 2007, København, 168-193.

Jørgensen, Aage (2009), "Finest frugt - om 'den Vartou Kjællingepræst': En guide til Grundtvig-Studier 1948-2008, I" i Grundtvig-Studier 2009, København, 20-85.

Lindhardt, P. G. (1974), Konfrontation, København.

MacIntyre, Alasdair (1981), After Virtue. A Study in Moral Theory, Notre Dame, Frankrig.

McDowell, John (1998), Mind, Value, and Reality, Cambridge.

Swanton, Christine (2003), Virtue ethics, a pluralistic view, Oxford.

Thaning, Kaj (1963), Menneske først - Grundtvigs opgør med sig selv, bind $1-3$, København. 